\title{
Degree of mismatch between anthropometric characteristics and school furniture in a sample of Spanish students aged 6-12 years old: A pilot study
}

\author{
Prof. Iván Prieto-Lage, M.D. ${ }^{a, b}$, Prof. Carlos Ayán, M.D. ${ }^{a}$, \\ Prof. Diego Alonso-Fernández, M.D. ${ }^{a}$, Adrián Paramés-González, Magister ${ }^{a, b}$, \\ Juan Carlos Argibay-González, Magistera,b, Emma M. Toboada-Solla, B.S. ${ }^{a}$ and \\ Prof. Alfonso Gutiérrez-Santiago, M.D..$^{a, b}$
}

\begin{abstract}
Introduction. School furniture affects the sitting position of students in the classroom, as well as their health and learning. Therefore, it is necessary to determine the existence of a potential mismatch between school furniture dimensions and students' anthropometric characteristics, as well as to propose dimensions based on classroom actuality and the regulations in place in both Galicia and the European Union.

Population and methods. An evaluator with experience in anthropometry measured weight, height, popliteal height, sitting shoulder height, and sitting elbow height using an anthropometer and then compared values with the chairs and desks currently used. Analysis techniques were descriptive (measures of central tendency), single-factor analysis of variance, $t$ test, $\chi^{2}$ test (using the SPSS ${ }^{\circledR}$ software), and effect size (Cohen's $d$ test). The significance level was established at $p \leq 0.05$.

Results. The sample was made up of 108 Spanish children in primary school (aged 6-12 years). Of them, $91.7 \%$ and $97.2 \%$ use, respectively, a chair and a desk that do not adjust to their anthropometric characteristics and use furniture that is larger than what they need. The regulations for furniture dimensions currently in place for the studied population are not adequate because the chairs and desks included are not adequate for the first grades of primary school.

Conclusions. There is a high mismatch level between school furniture and students' anthropometric characteristics. We propose the use of the European regulations for furniture dimensions, with varying heights per grade or adjustable furniture that can be adapted to the anthropometric characteristics of all students. Key words: education, ergonomics, anthropometry, interior design and furniture, needs assessment.
\end{abstract}

http: / / dx.doi.org/10.5546/aap.2021.eng.386

To cite: Prieto-Lage I, Ayán C, Alonso-Fernández D, Paramés-González A, et al. Degree of mismatch between anthropometric characteristics and school furniture in a sample of Spanish students aged 6-12 years old: A pilot study. Arch Argent Pediatr 2021;119(6):386-393.

\section{INTRODUCTION}

Students spend approximately 6.5 hours a day at school ${ }^{1,2}$ and, between $70 \%$ and $90 \%$ of that time, they are sitting. ${ }^{3,4}$ Such situation increases the risk for musculoskeletal problems at an early age, including neck, back or shoulder pain, as a result of a mismatch between students' anthropometric characteristics and school furniture dimensions. ${ }^{5}$ In addition, academic performance may also be affected because an uncomfortable body posture hinders learning, ${ }^{6,7}$ thus increasing fatigue and resulting in impaired attention, which is critical for the learning process. ${ }^{5}$ Considering that school is an ideal setting for the acquisition of healthy habits that can continue into adulthood, ${ }^{8}$ it is necessary to implement actions to identify ideal school furniture dimensions. In some countries, this situation has been resolved through standards for school furniture design, such as Chile, ${ }^{9}$ Japan ${ }^{10}$ or Korea. ${ }^{11}$ In Spain, the European Union (EU $)^{12}$ has issued, relatively recently, guidelines that remain to be implemented. This results in outdated guidelines regarding adequate school furniture design and dimensions. An example of this is the region of Galicia, where a school furniture 2007 catalog for primary school (PS) is available, ${ }^{13}$ but no dimension matches the EU reference report. ${ }^{12}$

This study has two objectives. First of all, to determine the existence of a potential mismatch between 
school furniture dimensions and anthropometric measures in a group of students aged 6-12 years. Secondly, to propose furniture distribution based on classroom actuality and in accordance with the Galicia and EU regulations.

\section{POPULATION AND METHODS Population}

Study participants were students from a public primary school located in a city of Galicia, in the northwest region of Spain, during the 20192020 school year. The sample was selected by convenience to facilitate student recruitment. All students aged 6-12 years who delivered the informed consent signed by their parents or legal guardians and their own authorization were included in the study.

All relevant authorizations for the study were requested from the school's administration. The study objectives, procedures, confidentiality statement, and the investigator's contact information were described to all students and their families before the study. The ethical principles for medical research involving human subjects established by the Declaration of Helsinki ${ }^{14}$ were followed at all times. The study was approved by the Ethics Committee of the School of Education and Sports Sciences of Universidade de Vigo under code 04/1019.

\section{Assessments}

Anthropometric measurements were taken following the procedure established in other similar studies. ${ }^{5}$ For the assessment, students' measurements were taken on the right side (except height and weight), with the participant sitting on an adjustable-height chair with a horizontal surface seat, with the legs flexed at $90^{\circ}$ and the feet resting on an adjustable footrest. During the measurement process, the participant was barefoot and wearing pants and a T-shirt. Measurements were taken using a Cescorf ${ }^{\circledR}$ anthropometer $(60 \mathrm{~cm})$ approved by the International Society for the Advancement of Kinanthropometry (ISAK), except for height, which was measured using a portable Seca ${ }^{\circledR}$ stadiometer $(20-205 \mathrm{~cm})$ and weight, for which a Tanita UM-076 ${ }^{\circledR}$ scale was used. Measurements were taken twice by the same anthropometrist and recorded in centimeters by an assistant. This allowed to minimize errors resulting from multiple anthropometrists taking measurements. ${ }^{15}$ Precision and repeatability were ensured by training the anthropometrist, who had an ISAK
3 certificate and previous experience in this type of assessment. Each parameter was measured at least twice, and if values showed a difference of more than $0.5 \mathrm{~cm}$, an additional measurement was taken. The following anthropometric measures were considered to estimate ideal furniture dimensions: ${ }^{16}$

- Height: vertical distance from the floor to the top of the head, with the subject standing upright and looking straight ahead (Frankfurt plane).

- Shoulder height sitting (SHS): vertical distance from the subject's seated surface to the acromion.

- Elbow height sitting (EHS): measured with the elbow flexed at $90^{\circ}$. It is the vertical distance from the tip of the elbow (olecranon) to the subject's seated surface.

- Popliteal height (PH): measured with the knees flexed at $90^{\circ}$. It is the vertical distance from the floor to the posterior surface of the knee (popliteal surface).

Collected anthropometric data were compared to furniture dimensions to identify whether there was an agreement or mismatch. Mismatch was defined as the disagreement between current furniture dimensions and students' anthropometric characteristics based on the following formulas to estimate ideal measures: ${ }^{17}$

- Seat height (SH): $(\mathrm{PH}+2.5) \cos 30 \leq \mathrm{SH} \leq(\mathrm{PH}+2.5) \cos 5$.

- Desk height $(\mathrm{DH})$ : $(\mathrm{SH}+\mathrm{EHS} \leq \mathrm{DH} \leq(\mathrm{SH}+\mathrm{EHS} \times 0.7396+\mathrm{SHS}$ $x$ 0.2604).

\section{Procedure}

The chairs and desks used by students on a daily basis were measured for their subsequent analysis and comparison: ${ }^{17}$

- Current chair height: vertical distance from the floor to the middle of the front edge of the seat surface.

- Current desk height: vertical distance from the floor to the upper part of the front edge of the desk.

Anthropometric measurements were taken in 2 consecutive days. Assessments were performed during school hours, between 9 a.m. and 2 p.m., with first, second, and third grades tested on the first day and the rest, the following day, during the first week of April.

\section{Statistical analysis}

All statistical analyses were done with the Statistical Package for the Social Sciences 
software, version $20.0^{\circledR}$ (IBM-SPSS Inc., Chicago, USA). A descriptive analysis, stratified by grade, was done of each study target variable using measures of central tendency (mean and standard deviation). The Kolmogorov-Smirnov test confirmed the sample's normality. The mean values of parameters obtained for the different grades were compared using a single-factor analysis of variance (ANOVA), applying a post hoc Tukey's b test if differences were statistically significant $(p<0.05)$. Such mean values were also compared between males and females, using a $\mathrm{t}$ test for independent samples for quantitative variables and a $\chi^{2}$ test for qualitative variables.

The $t$ test was used to compare mean values for related samples to check for differences between ideal and actual furniture dimensions. Qualitative variables were compared using the $\chi^{2}$ test. In addition, based on quantitative variables, the effect size was analyzed using
Cohen's $d$ test $(d<0.2$ : null; $d=0.2-0.49$ : small; $d=0.5-0.8$ : moderate; and $d>0.8$ : large). For all statistical tests, a value of $p<0.05$ was considered significant.

\section{RESULTS}

A total of 110 students ( 66 boys and 44 girls) enrolled in the school and aged 6-12 years were invited to participate; of these, 2 were not authorized by their family. The final sample was made up of 108 students (mean age: 9.49 years; $52 \%$ boys and $48 \%$ girls). Their anthropometric characteristics and the height of the school furniture are described in Table 1. The results showed significant differences in anthropometric records by grade $(p<0.0005)$. No significant differences were observed in each grade by sex.

Table 2 shows the mean chair and desk height by grade used by students before the study (actual height) and that subsequently established as ideal height.

TABLE 1. Descriptive analysis and single-factor analysis of variance (ANOVA) of anthropometric values of students by grade

\begin{tabular}{|c|c|c|c|c|c|c|}
\hline Grade & $\begin{array}{c}\text { Age interval } \\
\text { (years) }\end{array}$ & $\begin{array}{l}\text { Height } \\
\text { (cm) }\end{array}$ & $\begin{array}{l}\text { Weight } \\
\text { (kg) }\end{array}$ & $\begin{array}{l}\text { Popliteal height } \\
\text { (cm) }\end{array}$ & $\begin{array}{l}\text { Elbow height } \\
\text { (cm) }\end{array}$ & $\begin{array}{l}\text { Shoulder height } \\
\text { (cm) }\end{array}$ \\
\hline $\begin{array}{l}1^{\text {st }} \text { grade PS } \\
\mathrm{n}=11\end{array}$ & $6-7$ & $122.1 \pm 5.5^{\mathrm{a}}$ & $27.2 \pm 3.9^{\mathrm{e}}$ & $29.3 \pm 1.6^{g}$ & $15.0 \pm 2.0^{\mathrm{i}}$ & $40.1 \pm 2.6^{\mathrm{e}}$ \\
\hline $\begin{array}{l}2^{\text {nd }} \text { grade PS } \\
\mathrm{n}=13\end{array}$ & $7-8$ & $126.6 \pm 6.0^{\mathrm{a}, \mathrm{b}}$ & $32.3 \pm 9.2^{\mathrm{e}, \mathrm{f}}$ & $31.3 \pm 1.1^{\mathrm{b}}$ & $15.5 \pm 2.4^{\mathrm{i}}$ & $42.3 \pm 2.9^{e, j}$ \\
\hline $\begin{array}{l}3^{\text {rd }} \text { grade PS } \\
n=19\end{array}$ & $8-9$ & $130.3 \pm 6.8^{b}$ & $31.2 \pm 6.1^{\mathrm{e}, \mathrm{f}}$ & $32.6 \pm 2.2^{\mathrm{b}}$ & $14.5 \pm 1.9^{\mathrm{i}}$ & $42.1 \pm 2.7^{e, j}$ \\
\hline $\begin{array}{l}4^{\text {th }} \text { grade PS } \\
n=16\end{array}$ & $9-10$ & $138.9 \pm 8.7^{c}$ & $39.7 \pm 13.8^{\mathrm{f}}$ & $35.7 \pm 2.6^{c}$ & $15.4 \pm 2.8^{\mathrm{i}}$ & $44.7 \pm 3.8^{j}$ \\
\hline $\begin{array}{l}5^{\text {th }} \text { grade PS } \\
n=21\end{array}$ & $10-11$ & $143.6 \pm 7.5^{c}$ & $39.8 \pm 9.4^{\mathrm{f}}$ & $36.9 \pm 2.0^{\mathrm{c}, \mathrm{h}}$ & $16.6 \pm 1.6^{\mathrm{h}, \mathrm{i}}$ & $47.4 \pm 2.7^{\mathrm{k}}$ \\
\hline $\begin{array}{l}6^{\text {th }} \text { grade PS } \\
n=28\end{array}$ & $11-12$ & $150.1 \pm 6.7^{\mathrm{d}}$ & $51.5 \pm 12.3^{\mathrm{d}}$ & $38.5 \pm 1.5^{\mathrm{h}}$ & $18.2 \pm 2.3^{h}$ & $50.1 \pm 2.7^{\mathrm{d}}$ \\
\hline ANOVA & $\begin{array}{c}\mathrm{F} \\
\mathrm{g} / \mathrm{L} \\
\mathrm{Sig}\end{array}$ & $\begin{array}{c}41.66 \\
5 \\
0.00^{*}\end{array}$ & $\begin{array}{c}14.78 \\
5 \\
0.00^{*}\end{array}$ & $\begin{array}{c}60.55 \\
5 \\
0.00^{*}\end{array}$ & $\begin{array}{c}8.34 \\
5 \\
0.00^{*}\end{array}$ & $\begin{array}{c}31.97 \\
5 \\
0.00^{*}\end{array}$ \\
\hline
\end{tabular}

PS: primary school.

${ }^{*} p<0.05$.

Significance relation among academic grades:

${ }^{a} 1^{\text {st }}$ and $2^{\text {nd }}$ show differences with the rest.

${ }^{b} 2^{\text {nd }}$ and $3^{\text {rd }}$ show differences with the rest.

${ }^{\mathrm{c}} 4^{\text {th }}$ and $5^{\text {th }}$ show differences with the rest.

${ }^{\mathrm{d}} 6^{\text {th }}$ shows differences with the rest.

${ }^{\mathrm{e}} 1^{\text {st }}$ to $3^{\text {rd }}$ show differences with the rest.

${ }^{\mathrm{f}} 2^{\text {nd }}$ to $5^{\text {th }}$ show differences with the rest.

${ }^{\mathrm{g}} 1^{\text {st }}$ shows differences with the rest.

$\mathrm{h} 5^{\text {th }}$ and $6^{\text {th }}$ show differences with the rest.

${ }^{\mathrm{i}} 1^{\text {st }}$ to $5^{\text {th }}$ show differences with the rest.

i $2^{\text {nd }}$ to $4^{\text {th }}$ show differences with the rest.

${ }^{k} 5^{\text {th }}$ shows differences with the rest. 
Figure 1 describes the analysis of school furniture mismatch by grade. Results demonstrate the existence of a mismatch between anthropometric characteristics and the height of furniture in use. It was observed that $91.7 \%$ and $97.2 \%$ of study participants used a chair and desk that did not adjust to their anthropometric characteristics, respectively.

Students sit on a chair that is between $2 \mathrm{~cm}$ and $8 \mathrm{~cm}$ larger than the size appropriate for them and use a desk that is between $7 \mathrm{~cm}$ and $10 \mathrm{~cm}$ taller than the ideal height.

In relation to ideal chair and desk dimensions, as well as the minimum and maximum recommended range, statistically significant differences were observed among grades $(p<0.0005)$. No statistically significant differences were noted in terms of participant sex, except for the ideal chair height variable in $2^{\text {nd }}$ grade $(p=0.007)$.

The analysis of the effect size (Cohen's $d$ test) for the ideal chair height indicates that the differences between both groups are moderate $(d=0.74)$. The $t$ test for related samples between actual and ideal furniture height after the anthropometric analysis shows statistically significant differences $(p<0.0005)$ in all comparisons. The effect size analysis (Cohen's

TABLE 2. Comparison among grades using a single-factor analysis of variance (ANOVA) of actual and ideal height of chairs and desks and comparison by grade between actual and ideal height of chairs and desks ( $t$ test)

\begin{tabular}{|c|c|c|c|c|c|c|c|c|c|c|c|c|c|}
\hline \multirow[t]{2}{*}{ Grade } & \multirow[t]{2}{*}{$\begin{array}{c}\text { Age } \\
\text { (years) }\end{array}$} & \multirow{2}{*}{$\begin{array}{c}\text { Actual } \\
\text { height of } \\
\text { chair }(\mathrm{cm})\end{array}$} & \multirow{2}{*}{$\begin{array}{c}\text { Ideal height } \\
\text { of chair }(\mathrm{cm}) \\
\text { Range of } \\
\text { ideal chair } \\
\text { height }(\mathrm{cm})\end{array}$} & \multicolumn{2}{|c|}{$t$ test } & \multicolumn{2}{|c|}{$\begin{array}{l}\text { Cohen's } \\
d \text { test }\end{array}$} & \multirow{2}{*}{$\begin{array}{c}\text { Actual } \\
\text { height of } \\
\text { desk }(\mathrm{cm})\end{array}$} & \multirow{2}{*}{$\begin{array}{c}\text { Ideal height } \\
\text { of desk }(\mathrm{cm}) \\
\text { Range of } \\
\text { ideal desk } \\
\text { height }(\mathrm{cm})\end{array}$} & \multicolumn{2}{|c|}{$t$ test } & \multicolumn{2}{|c|}{$\begin{array}{c}\text { Cohen's } \\
d \text { test }\end{array}$} \\
\hline & & & & ) & $\mathrm{p}$ & d & $\mathbf{r}$ & & & $\mathbf{t}$ & p & d & $\mathbf{r}$ \\
\hline $\begin{array}{l}1^{\text {st }} \text { grade PS } \\
n=11\end{array}$ & $6-7$ & $37.1 \pm 1.8$ & $\begin{array}{c}29.6 \pm 1.5^{\mathrm{a}} \\
(27.5 \pm 1.4 / \\
31.7 \pm 1.6)\end{array}$ & 9.041 & $.000^{*}$ & 4.5 & 0.9 & $59.7 \pm 1.5$ & $\begin{array}{c}47.9 \pm 2.5^{\mathrm{e}} \\
(44.6 \pm 2.4 / \\
51.1 \pm 2.6)\end{array}$ & 19.127 & $.000^{*}$ & 5.7 & 0.9 \\
\hline $\begin{array}{l}2^{\text {nd }} \text { grade PS } \\
n=13\end{array}$ & $7-8$ & $37.8 \pm 2.0$ & $\begin{array}{c}31.4 \pm 1.0^{\mathrm{b}} \\
(29.2 \pm 0.9 / \\
33.7 \pm 1)\end{array}$ & 10.069 & $.000^{*}$ & 4.0 & 0.9 & $60.5 \pm 2.4$ & $\begin{array}{r}50.4 \pm 2.6^{\mathrm{b}, \mathrm{e}} \\
(46.9 \pm 2.5 / \\
53.9 \pm 2.7)\end{array}$ & 11.512 & $.000^{*}$ & 4.0 & 0.9 \\
\hline $\begin{array}{l}3^{\text {rd }} \text { grade PS } \\
n=19\end{array}$ & $8-9$ & $42.7 \pm 2.7$ & $\begin{array}{c}32.7 \pm 2.0^{\mathrm{b}} \\
(30.4 \pm 1.9 / \\
35.0 \pm 2.2)\end{array}$ & 11.227 & $.000^{*}$ & 3.8 & 0.9 & $64.8 \pm 2.9$ & $\begin{array}{c}50.8 \pm 3.0^{\mathrm{b}} \\
(47.2 \pm 2.9 / \\
54.4 \pm 3.2)\end{array}$ & 13.292 & $.000^{*}$ & 4.7 & 0.9 \\
\hline $\begin{array}{l}4^{\text {th }} \text { grade PS } \\
n=16\end{array}$ & $9-10$ & $42.4 \pm 1.4$ & $\begin{array}{c}35.6 \pm 2.5^{c} \\
(33.1 \pm 2.3 / \\
38.1 \pm 2.6)\end{array}$ & 11.579 & $.000^{*}$ & 3.4 & 0.9 & $66.0 \pm 0.0$ & $\begin{array}{c}54.8 \pm 4.8^{c} \\
(51.0 \pm 4.6 / \\
58.6 \pm 4.9)\end{array}$ & 9.401 & $.000^{*}$ & 3.3 & 0.9 \\
\hline $\begin{array}{l}5^{\text {th }} \text { grade PS } \\
n=21\end{array}$ & $10-11$ & $42.9 \pm 1.3$ & $\begin{array}{c}36.7 \pm 1.8^{\mathrm{c}, \mathrm{d}} \\
(34.1 \pm 1.7 / \\
39.3 \pm 1.9)\end{array}$ & 15.214 & $.000^{*}$ & 3.9 & 0.9 & $69.8 \pm 1.8$ & $\begin{array}{c}57.4 \pm 2.7^{c} \\
(53.4 \pm 2.6 / \\
61.4 \pm 2.8)\end{array}$ & 17.195 & $.000^{*}$ & 5.4 & 0.9 \\
\hline $\begin{array}{l}6^{\text {th }} \text { grade PS } \\
n=28\end{array}$ & $11-12$ & $42.5 \pm 1.5$ & $\begin{array}{l}38.2 \pm 1.4^{\mathrm{d}} \\
(35.6 \pm 1 / \\
40.9 \pm 1.5)\end{array}$ & 11.430 & $.000^{*}$ & 3.4 & 0.9 & $71.0 \pm 1.4$ & $\begin{array}{c}60.5 \pm 3.0^{f} \\
(56.4 \pm 2.9 / \\
64.7 \pm 3.0)\end{array}$ & 18.611 & $.000^{*}$ & 4.5 & 0.9 \\
\hline ANOVA F & & & 60.55 & & & & & 101.03 & 42.49 & & & & \\
\hline & $\mathrm{g} / 1$ & & 5 & & & & & 5 & 5 & & & & \\
\hline & Sig. & & $0.00^{*}$ & & & & & $0.00^{*}$ & $0.00^{*}$ & & & & \\
\hline
\end{tabular}

${ }^{*} \mathrm{p}<0.05$.

** For a better understanding of this table, it is reported that although the shorter chair and desk height proposed according to the furniture catalog for Galicia is $36 \mathrm{~cm}$ and $60 \mathrm{~cm}$, respectively, the study school used kindergarten furniture for the first primary school grades. Therefore, the table shows mean actual height values of classroom furniture that are lower than the lower values proposed in the furniture catalog for the Spanish region.

Significance relation among academic grades:

a 1st shows differences with the rest.

b 2nd and 3rd show differences with the rest.

c 4th and 5th show differences with the rest.

d 5th and 6th show differences with the rest.

e 1st and 2nd show differences with the rest.

$\mathrm{f}$ 6th shows differences with the rest.

Effect size: $\mathrm{d}$ and $\mathrm{r}, \mathrm{d}<0.2$ : null; $\mathrm{d}=0.2-0.49$ : small; $\mathrm{d}=0.5-0.80$ : moderate; and $\mathrm{d}>0.8$ : large. 
$d$ test) indicates that all differences were large $(d>0.8)$.

Table 3 shows the proposed ideal furniture based on students' anthropometric characteristics. In order to establish it, the current catalogs available for Galicia ${ }^{13}$ and the EU reference document ${ }^{12}$ were taken into consideration.

Figure 2 shows the degree of adjustment observed after reorganizing the school furniture at the reference school based on the EU regulations and the catalog for the region.

\section{DISCUSSION}

The objective of this study was to assess the degree of furniture adjustment based on the anthropometric characteristics of a group of students and to propose height values according to the classroom actuality and the Galicia and EU regulations.

According to the assessments, there is a mismatch between the anthropometric characteristics of students and school furniture dimensions; the percentage of students who use

FIGURE 1. Degree of adjustment of primary school (PS) furniture by grade. A: chair mismatch; : desk mismatch
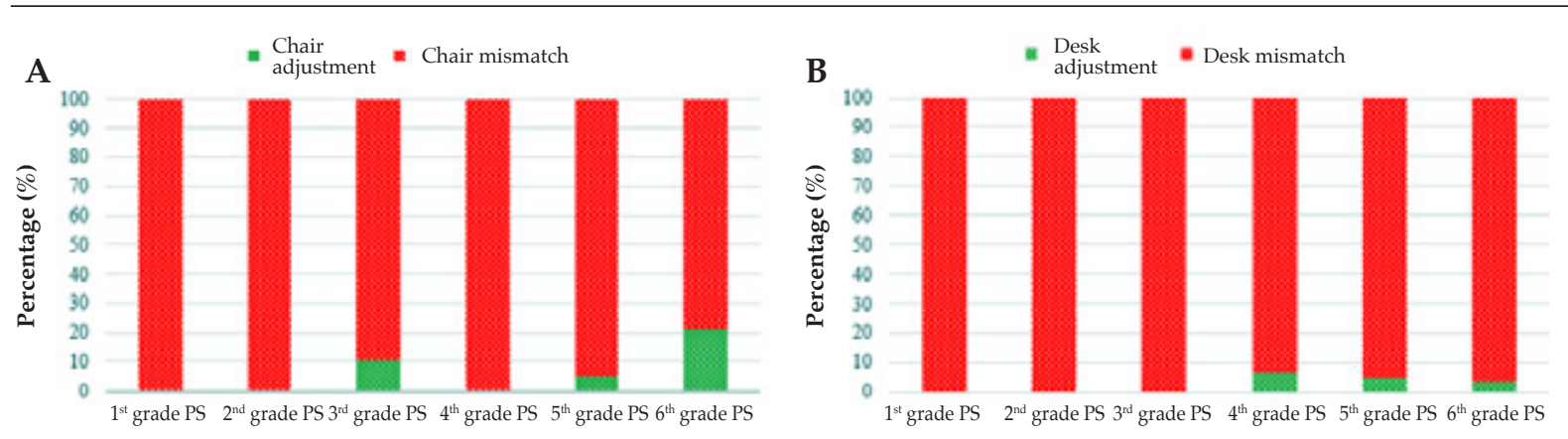

TABLE 3. Relation of recommended dimensions for the study school based on the regulations in place in the region of Galicia and the European Union

\begin{tabular}{lccccccccccc}
\hline & \multicolumn{3}{c}{ Chair height Galicia } & \multicolumn{3}{c}{ Chair height EU } & \multicolumn{2}{c}{ Desk height Galicia } & \multicolumn{2}{c}{ Desk height EU } \\
Grade & Height & Fre. & Perc. & Height & Fre. & Perc. & Height & Fre. & Perc. & Height & Fre. \\
Perc.
\end{tabular}

EU: European Union.

* Proposed measure recommended, but which is not currently available in the furniture regulations for the region of Galicia (kindergarten or primary school). The heights of $28 \mathrm{~cm}$ and $32 \mathrm{~cm}$ for chairs and $42 \mathrm{~cm}, 48 \mathrm{~cm}$, and $54 \mathrm{~cm}$ for desks are included based on a logical sequence of the expected change in dimensions.

${ }^{* *}$ Height as per the furniture catalog for the region of Galicia recommended for kindergarten (3-5 years old). 
a chair and a desk that are too large for them is extremely high. Such mismatch may lead to anatomical and functional disorders and learning difficulties and is in line with the reports of studies conducted in different continents. ${ }^{5}$ In North America, it was observed that students used an inadequate chair in up to $92 \%$ of cases and an inadequate desk in $95.1 \%$ of cases. ${ }^{18}$ High mismatch levels have been observed in Asian populations, ${ }^{19}$ where $92.5 \%$ and $100 \%$ of students used inadequate chairs and desks, respectively. In South America, in Chilean schools, more than $70 \%$ of students used an inadequate chair and, in $100 \%$ of cases, the desk height was wrong. ${ }^{20}$ Perú also reported high levels of mismatch. ${ }^{21}$ In Europe, studies conducted in the north of Portugal ${ }^{22}$ reported a $96 \%$ mismatch in relation to chairs and $76 \%$ in relation to desks.

Regarding Spanish standards, there is no state regulation in place, so the EU guidelines should be adhered to; ${ }^{12}$ however, they are not being followed. The reasons behind this may be that, on the one side, education responsibilities have been transferred, so each region is free to determine the type of furniture used in their schools. On the other side, according to the study results, regional administrations are not following any anthropometric criterion for proposed dimensions, and school furniture design and dimensions guidelines are outdated because the currently valid regulations in Galicia were passed in 2007. The hurdle of facing an investment in new furniture due to its high cost may also be a reason. ${ }^{23,24}$ The results obtained in this study suggest that, for the target population, the EU catalog ${ }^{12}$ should be followed to establish furniture height, which helps to adapt both chairs and desks to students' characteristics. Thus, 5 chair heights $(26,31,35,38$, and $43 \mathrm{~cm})$ and 4 desk heights $(46,53,59$, and $64 \mathrm{~cm})$ would be required. With the current catalog used in Galicia, ${ }^{13}$ total adjustment is possible only in $5^{\text {th }}$ and $6^{\text {th }}$ grade of PS (10-12 year old students). For the remaining grades, furniture not designed for PS should be used. The most prominent example that is worth noting is that all $1^{\text {st }}$ grade students of PS use inadequate furniture. If $1^{\text {st }}$ grade of PS was assigned the furniture established by regulations to kindergarten, only $45.5 \%$ of students would fit in their chairs and $9.1 \%$ in their desks. The remaining students would not find a chair and a desk that is appropriate for their anthropometric characteristics in the furniture catalog of Galicia. If the school had furniture that met the EU regulations, all students may have access to an adequate distribution. In turn, statistically significant differences were observed in chair and desk height that should be used by students per grade, so it was not possible to establish a single height by grade or age; instead, we propose furniture dimensions by level of maturation. These findings are consistent with the conclusions obtained in other studies ${ }^{22,25}$ and evidence the variability in anthropometric characteristics of PS students. It is necessary to have 2 or 3 different chair and desk heights available in each grade or adjustable furniture. ${ }^{24,26}$

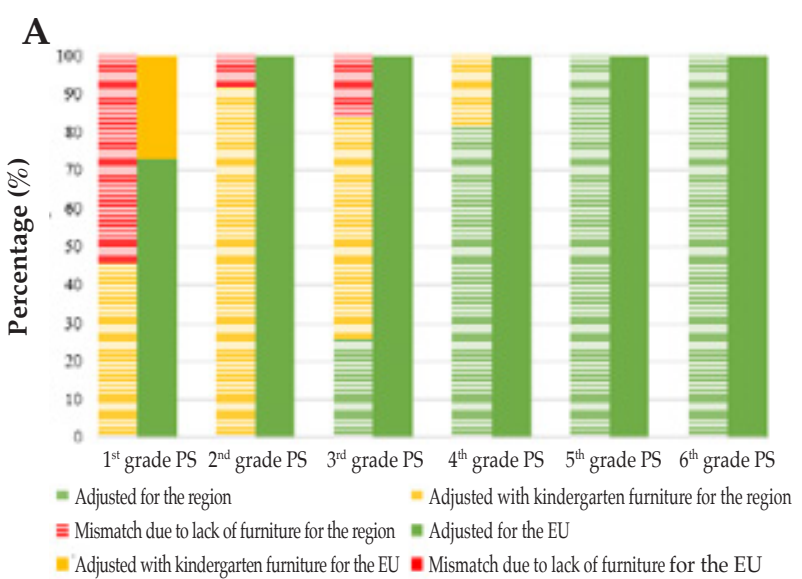

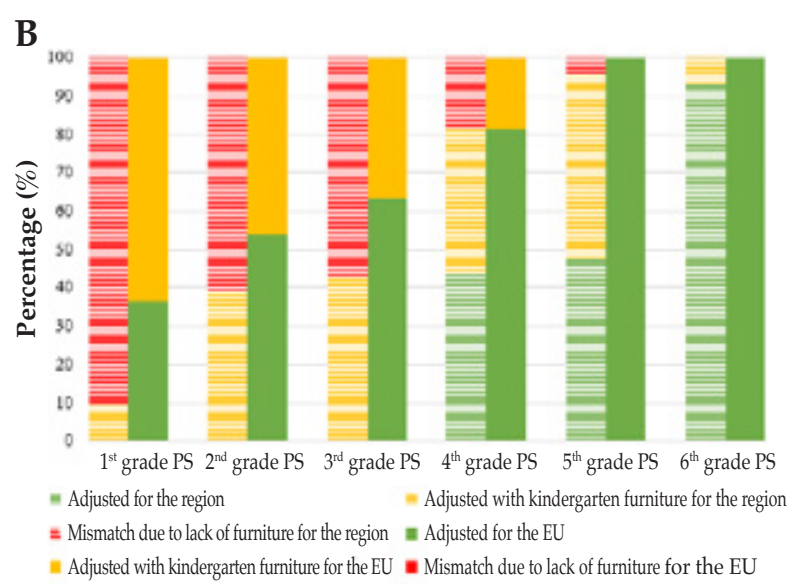




\section{Limitations}

This study has some methodological weaknesses, including a reduced sample size, from a single public school, or the comparative analyses between the different small groups, both in terms of analysis by grade or by sex. These limitations should therefore be taken into account because they restrict result interpretation and transference, given that this sample is not representative of the region. In addition, no instrument was used to look for musculoskeletal diseases. However, the findings may be indicative of a similar problem in Spain and other countries, so further studies with larger samples of students are required.

\section{CONCLUSIONS}

There is a mismatch between the anthropometric characteristics of students and school furniture dimensions, with a high percentage of students using chairs and desks that are too big for them.

The current furniture catalog used in the region is inadequate because it does not meet anthropometric adjustment criteria. However, the height indicated in the European Union catalog correctly adapts to the reference sample, so it is necessary to use varying height furniture by grade or adjustable furniture that adapts to the anthropometric characteristics of all students.

\section{REFERENCES}

1. Cooper AR, Goodman A, Page AS, Sherar LB, et al. Objectively measured physical activity and sedentary time in youth: The International Children'S Accelerometry Database (ICAD). Int Behav Nutr Phys Act. 2015; 12:113.

2. Janssen X, Mann KD, Basterfield L, Parkinson KN, et al. Development of sedentary behavior across childhood and adolescence: Longitudinal analysis of the Gateshead Millennium Study. Int J Behav Nutr Phys Act. 2016; 13:88.

3. Mooses K, Mägi K, Riso EM, Kalma M, et al. Objectively measured sedentary behaviour and moderate and vigorous physical activity in different school subjects: a crosssectional study. BMC Public Health. 2017; 17(1):108.

4. Ridgers ND, Salmon J, Ridley K, O'Connell E, et al. Agreement between activPAL and ActiGraph for assessing children's sedentary time. Int J Behav Nutr Phys Act. 2012; 9:15.

5. Castellucci HI, Arezes PM, Molenbroek JFM, de Bruin R, Viviani C. The influence of school furniture on students' performance and physical responses: results of a systematic review. Ergonomics. 2016; 60(1):93-110.

6. Mura G, Vellante M, Nardi A, Machado S, Carta M. Effects of school-based physical activity interventions on cognition and academic achievement: a systematic review. CNSNeurol Disord Drug Targets. 2015; 14(9):1194-208.
7. Fettweis T, Demoulin C, Vanderthommen M. Influence de la position assise d'enfants sur leurs capacités cognitives. Kinésithérapie. 2013; 13(136):20-5.

8. Wick K, Faude O, Manes S, Zahner L, Donath L. I can stand learning: A controlled pilot intervention study on the effects of increased standing time on cognitive function in primary school children. Int J Environ Res Public Health. 2018; 15(2):356.

9. Instituto Nacional de Normalización. Norma chilena 2566. Mobiliario escolar de silla y mesas escolares y requisitos dimensionales. Santiago de Chile: INN; 2002.

10. JapaneseStandards Association. JISS1021School furnitureDesk and chairs for general learning space. Tokyo: Japanese Industrial Standards; 2011.

11. Korean Industrial Standards. KS G 2010:2015 Chairs and Tables for Educational Institutions. Korea: KIS; 2015.

12. European Committee for Standadization CEN. Furniture - Chairs and tables for educational institutions - Part 1: Functional dimensions. Brussels: CEN; 2015.

13. Xunta deGalicia. Equipamento de centros: catálogos xerais [Internet]. Galicia: Conselleria de Educación, Universidad en e Formación Profesional; 2017 [Accessed on: March 1"st, 2021]. Available at: https:/ / www.edu.xunta.gal/portal/ node / 495

14. Harriss DJ, Atkinson G. Ethical Standards in Sport and Exercise Science Research: 2016 Update. Int J Sports Med. 2015; 36(14):1121-4.

15. Bragança S, Arezes P, Carvalho M, Ashdown SP, et al. A comparison of manual anthropometric measurements with Kinect-based scanned measurements in terms of precision and reliability. Work. 2018; 59(3):325-39.

16. ISO. ISO 7250-1: Basic human body measurements for technological design-Part 1:Body measurement definitions and landmarks. $2^{\text {nd }}$ ed. Geneva: International Organization for Standardization; 2017.

17. Castellucci HI, Arezes PM, Molenbroek JFM. Applying different equations to evaluate the level of mismatch between students and school furniture. Appl Ergon. 2014; 45(4):112332.

18. Brewer JM, Davis KG, Dunning KK, Succop PA. Does ergonomic mismatch at school impact pain in school children? Work. 2009; 34(4):455-64.

19. Parvez MS, Parvin F, Shahriar MM, Kibria G. Design of Ergonomically Fit Classroom Furniture for Primary Schools of Bangladesh. J Eng (United Kingdom). 2018; 2018:3543610.

20. Castellucci HI, Catalán M, Arezes PM, Molenbroek JFM. Evaluation of the match between anthropometric measures and school furniture dimensions in Chile. Work. 2016; 53(3):585-95.

21. Manrique-Olivares D, Quispe-Montoya K. ¿Es el mobiliario escolar adecuado para los estudiantes? Evaluación de una muestra de escolares peruanos. Arch Argent Pediatr. 2016; 114(1):e70.

22. Macedo AC, Morais AV, Martins HF, Martins JC, et al. Match between classroom dimensions and students' anthropometry: Re-equipment according to European educational furniture standard. Hum Factors. 2015;57(1):4860.

23. Da Silva LB, Coutinho AS, Da Costa Eulálio EJ, Soares EVG. School furniture and work surface lighting impacts on the body posture of Paraíba's public school students. Work. 2012; 42(4):579-87. 
24. Cantin N, Delisle I, Baillargeon M. Reducing ChildFurniture Incompatibility in Primary Schools. J Occup Ther Sch Early Interv. 2019; 12(2):200-9.

25. Lee Y, Yun MH. Evaluation of the guidelines and children's ability to select the anthropometrically recommendable height of school furniture: A case study of Korean primary school children. Work. 2019; 64(3):427-38.

26. Yanto, Lu CW, Lu JM. Evaluation of the Indonesian National Standard for elementary school furniture based on children's anthropometry. Appl Ergon. 2017; 62:168-81. 